\title{
Pibocella ponti gen. nov., sp. nov., a novel marine bacterium of the family Flavobacteriaceae isolated from the green alga Acrosiphonia sonderi
}

\author{
Correspondence \\ Olga I. Nedashkovskaya \\ olganedashkovska@piboc.dvo.ru \\ or \\ olganedashkovska@yahoo.com
}

\author{
Olga I. Nedashkovskaya, ${ }_{1}^{1}$ Seung Bum Kim, ${ }^{2} \dagger$ Kang Hyun Lee, ${ }^{2}$ \\ Kyung Sook Bae, ${ }^{2}$ Galina M. Frolova, ${ }^{1}$ Valery V. Mikhailov ${ }^{1}$ \\ and In Seop $\mathrm{Kim}^{3}$
}

\begin{abstract}
${ }^{1}$ Pacific Institute of Bioorganic Chemistry of the Far-Eastern Branch of the Russian Academy of Sciences, Pr. 100 Let Vladivostoku 159, 690022, Vladivostok, Russia

${ }^{2}$ Korean Collection for Type Cultures, Biological Resources Center, Korea Institute of Bioscience and Biotechnology, 52 Oun Dong, Yusong, Daejon 305-333, Republic of Korea

${ }^{3}$ Department of Biological Sciences, Hannam University, 133 Ojung Dong, Daejon 306-791, Republic of Korea
\end{abstract}

\begin{abstract}
A marine, heterotrophic, Gram-negative, aerobic, yellow-pigmented, bacterium that was motile by gliding, isolated from the green alga Acrosiphonia sonderi, was studied by polyphasic taxonomic methods. 16S rRNA gene sequence analysis indicated that strain $\mathrm{KMM} 6031^{\top}$ formed a distinct lineage within the family Flavobacteriaceae. On the basis of phenotypic, chemotaxonomic, genotypic and phylogenetic analyses, the novel bacterium was classified as Pibocella ponti

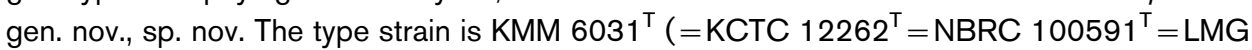
$22573^{\top}$ ).
\end{abstract}

The bacteria belonging to the family Flavobacteriaceae are one of the dominant groups of microbial populations inhabiting shallow marine environments and Antarctic meromictic lakes of marine origin (Bowman et al., 1997; Glöckner et al., 1999; Bano \& Hollibaugh, 2002; Kirchman, 2002; Van Trappen et al., 2002). Among flavobacteria, there are both halotolerant and moderately halophilic micro-organisms. The representatives of the genera Chryseobacterium, Flavobacterium, Formosa and Gillisia grow in the absence of $\mathrm{NaCl}$ or sea water in the nutrient medium (Vandamme et al., 1994; Bernardet et al., 1996; Ivanova et al., 2004; Van Trappen et al., 2004). However, the majority of members of the family Flavobacteriaceae require $\mathrm{Na}^{+}$ions for growth (Bernardet et al., 2002).

During investigation of the taxonomic diversity of the microbial population of the common green alga Acrosiphonia sonderi inhabiting the Sea of Japan, a novel moderately halophilic bacterium was isolated. Phylogenetic analysis based on 16S rRNA gene sequencing, supported by polyphasic taxonomic study, revealed that strain $\mathrm{KMM} 6031^{\mathrm{T}}$ is

Published online ahead of print on 30 July 2004 as DOI 10.1099/ ijs.0.63251-0.

tPresent address: Department of Microbiology, School of Bioscience and Biotechnology, Chungnam National University, Yusong, Daejon 305-764, Republic of Korea.

The GenBank/EMBL/DDBJ accession number for the 16S rRNA gene sequence of Pibocella ponti KMM $6031^{\top}$ is AY576654. a member of the family Flavobacteriaceae and represents a new genus and species, for which the name Pibocella ponti gen. nov., sp. nov. is proposed.

The strain KMM $6031^{\mathrm{T}}$ was isolated from a sample of the green alga Acrosiphonia sonderi collected in Troitsa Bay, Gulf of Peter the Great, Sea of Japan, during June 2000. For strain isolation, $0 \cdot 1 \mathrm{ml}$ homogenates of algal fronds were transferred onto plates of marine agar 2216. After primary isolation and purification, strains were cultivated at $28^{\circ} \mathrm{C}$ on the same medium and stored at $-80^{\circ} \mathrm{C}$ in marine broth supplemented with $20 \%$ (v/v) glycerol.

Genomic DNA extraction, PCR and sequencing of the 16S rRNA gene followed previous procedures (Kim et al., 1998). The sequence data obtained were aligned together with those of representative members of the family Flavobacteriaceae by using PHYDIT version 3.2 (http://plaza.snu.ac.kr/ $\sim$ jchun/phydit/). Phylogenetic trees were inferred by using suitable programs of the PHYLIP package (Felsenstein, 1993). Phylogenetic distances were calculated from the models of Kimura (1980) and the trees were constructed on the basis of the neighbour-joining (Saitou \& Nei, 1987), least-squares (Fitch \& Margoliash, 1967) and maximumlikelihood (Felsenstein, 1993) algorithms. Bootstrap analysis was performed with 1000 resampled datasets, using SEQBOOT and CONSENSE programs of the PHYLIP package.

A phylogenetic analysis of the almost-complete 16S rRNA 


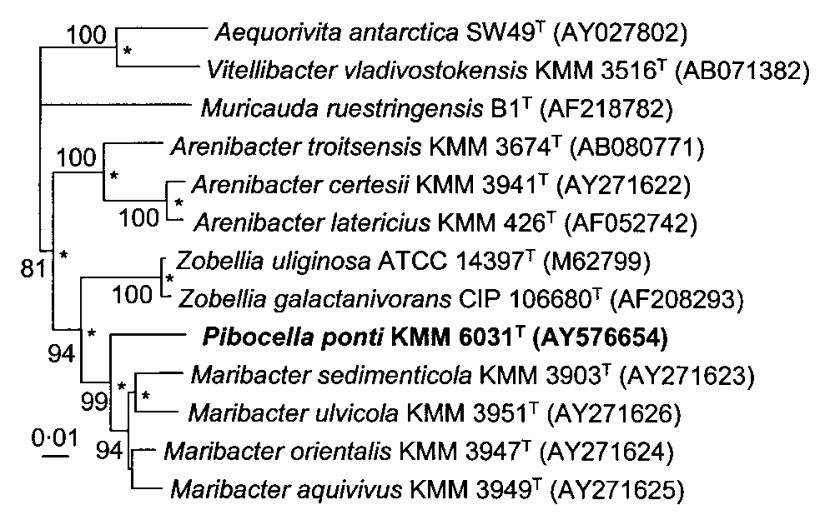

Fig. 1. Phylogenetic tree based on the 16S rRNA gene sequences of strain $\mathrm{KMM} 6031^{\top}$ and representative members of related genera in the family Flavobacteriaceae. The phylogenetic tree was generated by a neighbour-joining method (Saitou \& Nei, 1987). Numbers at nodes indicate bootstrap values (\%) and asterisks indicate branches that were also recovered in Fitch-Margoliash and maximum-likelihood trees. Bar, 0.01 substitutions per nucleotide position.

gene sequence (1447 nucleotide positions) revealed that strain KMM $6031^{\mathrm{T}}$ formed a distinct lineage within a cluster group including members of the family Flavobacteriaceae such as Aequorivita, Vitellibacter, Muricauda, Arenibacter, Zobellia and Maribacter (Fig. 1). The $16 \mathrm{~S}$ rRNA gene sequence similarity values of strain $\mathrm{KMM} 6031^{\mathrm{T}}$ and its close relatives Maribacter aquivivus, Maribacter orientalis and Maribacter ulvicola were $95 \cdot 8,95 \cdot 7$ and $95 \%$, respectively. The low levels of sequence similarity of the strain tested with the other members of the family Flavobacteriaceae described to date $(88 \cdot 9-93 \%)$ clearly demonstrate that the bacterium isolated in this study represents a new genus.

The DNA was extracted following the method of Marmur (1961) and the G+C content of the DNA (mol\%) was determined by the thermal denaturation method (Marmur \& Doty, 1962). The DNA G + C content of strain KMM $6031^{\mathrm{T}}$ was $35 \cdot 5 \mathrm{~mol} \%$.

The analysis of fatty acid methyl esters was carried out according to the standard protocol of the Microbial Identification System (Microbial ID). Isoprenoid quinones were extracted from lyophilized cells and analysed as described by Akagawa-Matsushita et al. (1992). Isoprenoid quinone composition was characterized by HPLC (Shimadzu instruments) using a reverse-phase type Zorbax ODS column $(250 \times 4 \cdot 6 \mathrm{~mm})$ and acetonitrile/2-propanol $(65: 35, \mathrm{v} / \mathrm{v})$ as a mobile phase at a flow rate of $0.5 \mathrm{ml} \mathrm{min}^{-1}$. The column was kept at $40^{\circ} \mathrm{C}$. Menaquinones were detected by monitoring absorbance at $270 \mathrm{~nm}$ and were identified by comparison with known quinones from reference strain Salegentibacter salegens DSM $5424^{\mathrm{T}}$.

The predominant cellular fatty acids of KMM $6031^{\mathrm{T}}$ were branched-chain saturated and unsaturated, namely i-15:0
Table 1. Whole-cell fatty acid profiles (percentage content) of Pibocella ponti gen. nov., sp. nov. KMM $6031^{\top}$ and Maribacter species

Strains: 1, Pibocella ponti KMM $6031^{\mathrm{T}}$; 2, Maribacter sedimenticola KMM 3903 ${ }^{\mathrm{T}}$; 3, Maribacter aquivivus KMM 3949 ${ }^{\mathrm{T}}$; 4, Maribacter ulvicola $\mathrm{KMM} 3951^{\mathrm{T}}$; 5, Maribacter orientalis $\mathrm{KMM} 3947^{\mathrm{T}}$. Data from Nedashkovskaya et al. (2004a) and this study. Values over $5 \%$ are in bold; - , not detected.

\begin{tabular}{|c|c|c|c|c|c|}
\hline Fatty acid & 1 & 2 & 3 & 4 & 5 \\
\hline $13: 1$ & $0 \cdot 1$ & $0 \cdot 7$ & $1 \cdot 1$ & $1 \cdot 1$ & $0 \cdot 3$ \\
\hline $\mathrm{i}-14: 0$ & $1 \cdot 0$ & - & - & - & - \\
\hline $14: 0$ & $0 \cdot 2$ & $0 \cdot 5$ & $1 \cdot 0$ & $0 \cdot 9$ & $0 \cdot 5$ \\
\hline $14: 1 \omega 5$ & - & - & $1 \cdot 0$ & $0 \cdot 9$ & - \\
\hline$i-15: 0$ & $8 \cdot 7$ & $20 \cdot 5$ & $12 \cdot 3$ & $13 \cdot 6$ & $10 \cdot 6$ \\
\hline$a-15: 0$ & $5 \cdot 4$ & $1 \cdot 2$ & $1 \cdot 3$ & $1 \cdot 9$ & $2 \cdot 3$ \\
\hline $\mathrm{i}-15: 1$ & $11 \cdot 7$ & $16 \cdot 9$ & $13 \cdot 6$ & $18 \cdot 9$ & $10 \cdot 1$ \\
\hline a-15:1 & $2 \cdot 1$ & - & - & - & - \\
\hline $15: 0$ & $4 \cdot 2$ & $6 \cdot 3$ & $14 \cdot 5$ & $8 \cdot 1$ & $12 \cdot 3$ \\
\hline $15: 1 \omega 6 c$ & $1 \cdot 5$ & $1 \cdot 7$ & $4 \cdot 8$ & $1 \cdot 6$ & $2 \cdot 5$ \\
\hline$i-16: 0$ & $12 \cdot 1$ & $1 \cdot 1$ & $0 \cdot 7$ & $0 \cdot 3$ & $0 \cdot 3$ \\
\hline $\mathrm{i}-16: 1$ & $6 \cdot 2$ & - & - & - & - \\
\hline $16: 0$ & $1 \cdot 0$ & $1 \cdot 0$ & $0 \cdot 5$ & $1 \cdot 0$ & $1 \cdot 2$ \\
\hline Summed feature $3^{\star}$ & $11 \cdot 4$ & $5 \cdot 8$ & $12 \cdot 9$ & $12 \cdot 2$ & $11 \cdot 4$ \\
\hline $\mathrm{i}-17: 1 \omega 5 c$ & - & - & $1 \cdot 4$ & $1 \cdot 2$ & - \\
\hline $\mathrm{i}-17: 1 \omega 9 c$ & $5 \cdot 2$ & $2 \cdot 3$ & $2 \cdot 2$ & $2 \cdot 2$ & $4 \cdot 0$ \\
\hline a-17: $1 \omega 9 c$ & $2 \cdot 3$ & - & - & - & - \\
\hline $17: 1 \omega 6 c$ & $4 \cdot 7$ & $0 \cdot 5$ & $1 \cdot 7$ & $0 \cdot 5$ & $1 \cdot 3$ \\
\hline $\mathrm{i}-15: 03-\mathrm{OH}$ & $0 \cdot 9$ & $5 \cdot 4$ & $3 \cdot 2$ & $4 \cdot 1$ & $2 \cdot 9$ \\
\hline $15: 03-\mathrm{OH}$ & - & $2 \cdot 4$ & $2 \cdot 3$ & $1 \cdot 5$ & $1 \cdot 5$ \\
\hline $15: 02-\mathrm{OH}$ & $1 \cdot 8$ & - & - & - & - \\
\hline $\mathrm{i}-16: 03-\mathrm{OH}$ & $5 \cdot 9$ & $1 \cdot 7$ & $2 \cdot 5$ & $1 \cdot 7$ & $2 \cdot 1$ \\
\hline $16: 03-\mathrm{OH}$ & $1 \cdot 0$ & $2 \cdot 2$ & $2 \cdot 9$ & $3 \cdot 7$ & $3 \cdot 0$ \\
\hline $\mathrm{i}-17: 03-\mathrm{OH}$ & $5 \cdot 6$ & $20 \cdot 4$ & $11 \cdot 6$ & $14 \cdot 5$ & $18 \cdot 8$ \\
\hline $17: 02-\mathrm{OH}$ & $2 \cdot 8$ & - & - & - & - \\
\hline $\mathrm{i}-18: 1$ & - & - & - & - & $2 \cdot 4$ \\
\hline Unknown & $5 \cdot 5$ & $7 \cdot 9$ & $10 \cdot 2$ & $10 \cdot 3$ & $5 \cdot 9$ \\
\hline
\end{tabular}

${ }^{\star}$ Summed feature 3 consists of $16: 1 \omega 7 c$ and/or i-15:0 2-OH.

$(8 \cdot 7 \%), a-15: 0(5 \cdot 4 \%), \mathrm{i}-15: 1(11 \cdot 7 \%), \mathrm{i}-16: 1(6 \cdot 2 \%)$, i-16:0 (12.1\%), i-17: $1 \omega 9 c(5 \cdot 2 \%)$, i-16:0 3-OH $(5 \cdot 9 \%)$ and $\mathrm{i}-17: 03-\mathrm{OH}(5 \cdot 6 \%)$ fatty acids (Table 1$)$. The major respiratory quinone is MK-6.

Phenotypic analysis was performed by using previously described methods (Nedashkovskaya et al., 2003a, b). Gliding motility was determined as described by Bowman (2000).

The physiological and biochemical characteristics of strain KMM $6031^{\mathrm{T}}$ are listed in the species description and Table 2. The phenotypic features that separate the strain studied from close relatives of the family Flavobacteriaceae are shown in Table 2. The results of phenotypic examination demonstrated that the strain studied has many traits in common with Maribacter species. However, strain KMM 
Table 2. Differential characteristics of Pibocella gen. nov. and other related genera of the family Flavobacteriaceae

Data from Barbeyron et al. (2001), Bruns et al. (2001), Ivanova et al. (2001), Bowman \& Nichols (2002), Nedashkovskaya et al. (2003b, c, $2004 \mathrm{a}, \mathrm{b}, \mathrm{c})$ and this study. + , Positive; -, negative; V, variable; ND, not determined. Members of all genera require $\mathrm{Na}^{+}$or sea water for growth.

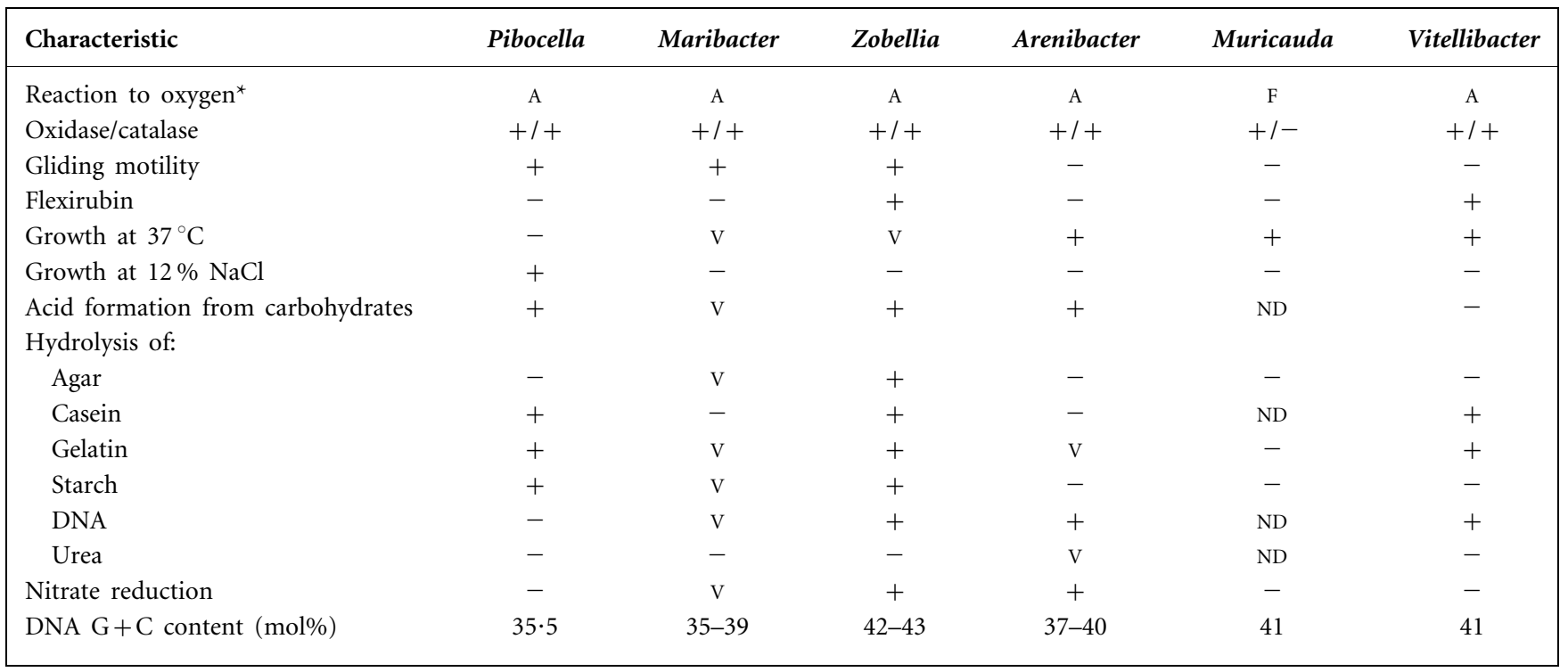

${ }^{\star}$ A, Aerobic; F, facultatively anaerobic.

$6031^{\mathrm{T}}$ grew at $12 \% \mathrm{NaCl}$ and degraded casein, in contrast to Maribacter species. Significant differences in the cellular fatty acid compositions of the strain studied and the type strains of the genus Maribacter were found (Table 1). For

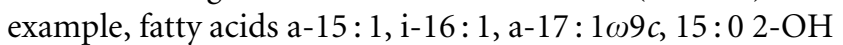
and 17:0 2-OH are present in $\mathrm{KMM} 6031^{\mathrm{T}}(2 \cdot 1,6 \cdot 2,2 \cdot 3$, $1 \cdot 8$ and $2 \cdot 8 \%$, respectively), but are absent in Maribacter

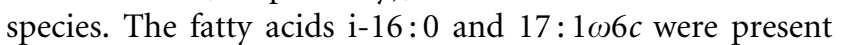
at significant levels in the cell extract of KMM $6031^{\mathrm{T}}(12 \cdot 1$ and $4.7 \%$, respectively), but are only minor components in type strains of Maribacter species $(0 \cdot 3-1 \cdot 1$ and $0 \cdot 5-1 \cdot 7 \%$, respectively). The hydroxy fatty acid $\mathrm{i}-15: 03-\mathrm{OH}$ was only found in minor quantities in the strain $\mathrm{KMM} 6031^{\mathrm{T}}(0 \cdot 9 \%)$, while in Maribacter species this component was more abundant, present at 2.9-5.4\%. In addition, $15: 03-\mathrm{OH}$, present at $1 \cdot 5-2 \cdot 4 \%$ in Maribacter type strains, was not detected in KMM $6031^{\mathrm{T}}$.

It is therefore evident from phylogenetic distinctness in combination with significant differences in cellular fatty acid composition and phenotypic findings, that the strain studied should be differentiated from its nearest neighbours Maribacter aquivivus, Maribacter orientalis and Maribacter ulvicola.

Thus, the results of the polyphasic analysis presented in this work demonstrate that the bacterium studied could not be assigned to any of the currently described taxa of the family Flavobacteriaceae and support the placement of strain KMM $6031^{\mathrm{T}}$ in a new genus, Pibocella gen. nov., as Pibocella ponti sp. nov.

\section{Description of Pibocella gen. nov.}

Pibocella [Pi.bo.cel'la. N.L. fem. n. Pibocella arbitrary name, derived from the acronym PIBOC (Pacific Institute of Bioorganic Chemistry, FEB RAS), where the type species was first isolated and examined].

Rod-shaped cells. Gram-negative. Do not form endospores. Motile by gliding. Strictly aerobic. Produce non-diffusible yellow-orange pigments. No flexirubins are formed. Chemo-organotrophs. Cytochrome oxidase-, catalase- and alkaline phosphatase-positive. The major respiratory quinone is MK-6. The main cellular fatty acids are straightchain unsaturated and branched-chain unsaturated fatty acids i-15:0, a-15:0, i-15:1, i-16:1, i-16:0, i-16:0 3-OH, $\mathrm{i}-17: 1 \omega 9 c, \mathrm{i}-17: 03-\mathrm{OH}$ and summed feature 3 , consisting of i15:0 2-OH and/or $16: 1 \omega 7 c$. As determined by $16 \mathrm{~S}$ rRNA gene sequence analysis, the genus Pibocella is a member of the family Flavobacteriaceae. The type species is Pibocella ponti.

\section{Description of Pibocella ponti sp. nov.}

Pibocella ponti (pon'ti. L. gen. n. ponti of the sea, a sea dweller).

Main characteristics are as given for the genus. In addition, cells range from 0.4 to $0.5 \mu \mathrm{m}$ in width and from 1.6 to $2 \cdot 3 \mu \mathrm{m}$ in length. On marine agar colonies are $2-4 \mathrm{~mm}$ in diameter, circular, shiny, convex with entire edges, yellow in colour. Grows at $4-33^{\circ} \mathrm{C}$; optimum temperature for growth is $21-23^{\circ} \mathrm{C}$. Growth occurs at $1-13 \% \mathrm{NaCl}$. Decomposes 
gelatin, casein, starch and Tweens 20, 40 and 80; does not hydrolyse agar, DNA, urea, cellulose (CM-cellulose and filter paper) or chitin. Forms acid from D-maltose, but not from L-arabinose, D-cellobiose, L-fucose, D-galactose, D-glucose, D-lactose, D-melibiose, L-raffinose, L-rhamnose, D-sucrose, DL-xylose, citrate, adonitol, dulcitol, glycerol, inositol or mannitol. Utilizes L-arabinose, D-glucose, D-mannose and D-sucrose, but not D-lactose, mannitol, inositol, sorbitol, malonate or citrate. Nitrate is not reduced. Indole, $\mathrm{H}_{2} \mathrm{~S}$ and acetoin (Voges-Proskauer reaction) production are negative. Susceptible to ampicillin, carbenicillin, lincomycin, oleandomycin, streptomycin and tetracycline; resistant to benzylpenicillin, gentamicin, kanamycin, neomycin and polymyxin $\mathrm{B}$. The predominant cellular fatty acids of $\mathrm{KMM} 6031^{\mathrm{T}}$ are branched-chain saturated and unsaturated, namely i-15:0 (8.7\%), a-15:0 (5.4\%), i-15: 1 $(11 \cdot 7 \%)$, i- $16: 1 \quad(6 \cdot 2 \%)$, i-16:0 (12.1\%), i- $17: 1 \omega 9 c$ $(5 \cdot 2 \%), \mathrm{i}-16: 03-\mathrm{OH}(5 \cdot 9 \%), \mathrm{i}-17: 03-\mathrm{OH}(5 \cdot 6 \%)$ and summed feature $3(11 \cdot 4 \%)$, consisting of $\mathrm{i}-15: 02-\mathrm{OH}$ and/ or $16: 1 \omega 7 c$. The major respiratory quinone is MK-6. The $\mathrm{G}+\mathrm{C}$ content of the DNA is $35 \cdot 5 \mathrm{~mol} \%$.

The type strain is KMM $6031^{\mathrm{T}}\left(=\mathrm{KCTC} 12262^{\mathrm{T}}=\mathrm{NBRC}\right.$ $100591^{\mathrm{T}}=\mathrm{LMG} 22573^{\mathrm{T}}$ ), isolated from the green alga Acrosiphonia sonderi collected in Troitsa Bay, Gulf of Peter the Great, Sea of Japan.

\section{Acknowledgements}

This research was supported by grants from the Federal Agency for Sciences and Innovations of the Ministry for Education and Sciences of the Russian Federation (no. 2-2.16), the Russian Foundation for Basic Research (no. 05-04-48211) and the Programme of Fundamental Investigations of the Presidium of the Russian Academy of Sciences 'Molecular and Cell Biology'. K. H. L. and S. B. K. are also grateful for support from the KRIBB Research Initiative Programme.

\section{References}

Akagawa-Matsushita, M., Itoh, T., Katayama, Y., Kuraishi, H. \& Yamasato, K. (1992). Isoprenoid quinone composition of some marine Alteromonas, Marinomonas, Deleya, Pseudomonas and Shewanella species. J Gen Microbiol 138, 2275-2281.

Bano, N. \& Hollibaugh, J. (2002). Phylogenetic composition of bacterioplankton assemblages from the Arctic Ocean. Appl Environ Microbiol 68, 505-518.

Barbeyron, T., L'Haridon, S., Corre, E., Kloareg, B. \& Potin, P. (2001). Zobellia galactanovorans gen. nov., sp. nov., a marine species of Flavobacteriaceae isolated from red alga, and classification of [Cytophaga] uliginosa (ZoBell and Upham 1944) Reichenbach 1989 as Zobellia uliginosa gen. nov., comb. nov. Int J Syst Evol Microbiol 51, 985-997.

Bernardet, J.-F., Segers, P., Vancanneyt, M., Berthe, F., Kersters, K. \& Vandamme, P. (1996). Cutting a Gordian knot: emended classification and description of the genus Flavobacterium, emended description of the family Flavobacteriaceae, and proposal of Flavobacterium hydatis nom. nov. (basonym Cytophaga aquatilis Strohl and Tait 1978). Int J Syst Bacteriol 46, 128-148.

Bernardet, J.-F., Nakagawa, Y. \& Holmes, B. (2002). Proposed minimal standards for describing new taxa of the family
Flavobacteriaceae and emended description of the family. Int J Syst Evol Microbiol 52, 1049-1070.

Bowman, J. P. (2000). Description of Cellulophaga algicola sp. nov., isolated from the surfaces of Antarctic algae, and reclassification of Cytophaga uliginosa (ZoBell and Upham 1944) Reichenbach 1989 as Cellulophaga uliginosa comb. nov. Int J Syst Evol Microbiol 50, 1861-1868.

Bowman, J. P. \& Nichols, D. S. (2002). Aequorivita gen. nov., a member of the family Flavobacteriaceae isolated from terrestrial and marine Antarctic habitats. Int J Syst Evol Microbiol 52, 1533-1541.

Bowman, J. P., McCammon, S. A., Brown, M. V., Nichols, D. S. \& McMeekin, T. A. (1997). Diversity and association of psychrophilic bacteria in Antarctic sea ice. Appl Environ Microbiol 63, 3068-3078.

Bruns, A., Rohde, M. \& Berthe-Corti, L. (2001). Muricauda ruestringensis gen. nov., sp. nov., a facultatively anaerobic, appendaged bacterium from German North Sea intertidal sediment. Int J Syst Evol Microbiol 51, 1997-2006.

Felsenstein, J. (1993). PHYLIP (phylogenetic inference package), version 3.5c. Department of Genetics, University of Washington, Seattle, USA.

Fitch, W. M. \& Margoliash, E. (1967). Construction of phylogenetic trees: a method based on mutation distances as estimated from cytochrome $\mathrm{c}$ sequences is of general applicability. Science 155, 279-284.

Glöckner, F. O., Fuchs, B. M. \& Amann, R. (1999). Bacterioplankton compositions of lakes and oceans: a first comparison based on fluorescence in situ hybridization. Appl Environ Microbiol 65, 3721-3726.

Ivanova, E. P., Nedashkovskaya, O. I., Chun, J. \& 7 other authors (2001). Arenibacter gen. nov., a new genus of the family Flavobacteriaceae and description of a new species, Arenibacter latericius sp. nov. Int J Syst Evol Microbiol 51, 1987-1995.

Ivanova, E. P., Alexeeva, Y. A., Flavier, S., Wright, J. P., Zhukova, N. V., Gorshkova, N. M., Mikhailov, V. V., Nicolau, D. V. \& Christen, R. (2004). Formosa algae gen. nov., sp. nov., a novel member of the family Flavobacteriaceae. Int J Syst Evol Microbiol 54, 705-711.

Kim, S. B., Falconer, C., Williams, E. \& Goodfellow, M. (1998). Streptomyces thermocarboxydovorans sp. nov. and Streptomyces thermocarboxydus sp. nov., two moderately thermophilic carboxydotrophic species isolated from soil. Int J Syst Bacteriol 48, 59-68.

Kimura, M. (1980). A simple method for estimating evolutionary rates of base substitutions through comparative studies of nucleotide sequences. J Mol Evol 16, 111-120.

Kirchman, D. I. (2002). The ecology of Cytophaga-Flavobacteria in aquatic environments. FEMS Microbiol Ecol 39, 91-100.

Marmur, J. (1961). A procedure for the isolation of deoxyribonucleic acid from microorganisms. J Mol Biol 3, 208-218.

Marmur, J. \& Doty, P. (1962). Determination of the base composition of deoxyribonucleic acid from its thermal denaturation temperature. J Mol Biol 5, 109-118.

Nedashkovskaya, O. I., Suzuki, M., Vysotskii, M. V. \& Mikhailov, V. V. (2003a). Reichenbachia agariperforans gen. nov., sp. nov., a novel marine bacterium in the phylum Cytophaga-FlavobacteriumBacteroides. Int J Syst Evol Microbiol 53, 81-85.

Nedashkovskaya, O. I., Suzuki, M., Vysotskii, M. V. \& Mikhailov, V. V. (2003b). Vitellibacter vladivostokensis gen. nov., sp. nov., a new member of the phylum Cytophaga-Flavobacterium-Bacteroides. Int J Syst Evol Microbiol 53, 1281-1286.

Nedashkovskaya, O. I., Suzuki, M., Vysotskii, M. V. \& Mikhailov, V. V. (2003c). Arenibacter troitsensis sp. nov., isolated from marine bottom sediment. Int J Syst Evol Microbiol 53, 1287-1290. 
Nedashkovskaya, O. I., Kim, S. B., Han, S. K. \& 7 other authors (2004a). Maribacter gen. nov., a new member of the family Flavobacteriaceae, isolated from marine habitats, containing the species Maribacter sedimenticola sp. nov., Maribacter aquivivus sp. nov., Maribacter orientalis sp. nov. and Maribacter ulvicola sp. nov. Int J Syst Evol Microbiol 54, 1017-1023.

Nedashkovskaya, O. I., Kim, S. B., Han, S. K., Lysenko, A. M., Mikhailov, V. V. \& Bae, K. S. (2004b). Arenibacter certesii sp. nov., a novel marine bacterium isolated from the green alga Ulva fenestrata. Int J Syst Evol Microbiol 54, 1173-1176.

Nedashkovskaya, O. I., Suzuki, M., Vancanneyt, M., Cleenwerck, I., Lysenko, A. M., Mikhailov, V. V. \& Swings, J. (2004c). Zobellia amurskyensis sp. nov., Zobellia laminariae sp. nov. and Zobellia russellii sp. nov., novel marine bacteria of the family Flavobacteriaceae. Int J Syst Evol Microbiol 54, 1643-1648.
Saitou, N. \& Nei, M. (1987). The neighbor-joining method: a new method for reconstructing phylogenetic trees. Mol Biol Evol 4, 406-425. Vandamme, P., Bernardet, J.-F., Segers, P., Kersters, K. \& Holmes, B. (1994). New perspectives in the classification of the flavobacteria: description of Chryseobacterium gen. nov., Bergeyella gen. nov. and Empedobacter nom. rev. Int J Syst Bacteriol 44, 827-831.

Van Trappen, S., Mergaert, J., Van Eygen, S., Dawyndt, P., Cnockaert, M. C. \& Swings, J. (2002). Diversity of 746 heterotrophic bacteria isolated from microbial mats from ten Antarctic lakes. Syst Appl Microbiol 25, 603-610.

Van Trappen, S., Vandecandelaere, I., Mergaert, J. \& Swings, J. (2004). Gillisia limnaea gen. nov., sp. nov., a new member of the family Flavobacteriaceae isolated from a microbial mat in Lake Fryxell, Antarctica. Int J Syst Evol Microbiol 54, 445-448. 